\title{
Audit Delay serta Faktor Internal Perusahaan : Studi Kasus Perusahaan Trade, Service, and Investment
}

\author{
Devi Dwi Yanti ${ }^{1}$, Rollickus Elta Zagoto ${ }^{2}$, Wenny Anggeresia Ginting ${ }^{3}$ \\ Universitas Prima Indonesia \\ Dvidwi27@gmail.com, zrollyck@gmail.com, gintinganggresiawenny@gmail.com
}

\author{
*Penulis Korespondensi \\ Diajukan : 14 April 2021 \\ Disetujui : $\quad 26$ April 2021 \\ Dipublikasi : 1 Agustus 2021
}

\begin{abstract}
The announcement from the Indonesia Stock Exchange on april 11, 2018, revealed that 70 companies have not submitted audited financial statements as of December 31, 2017, six of which are included in the trade, service, and investment sectors. Facts related to the rise of companies experiencing audit delays have been researched by several studies, but there are differences in results between researchers. Analyzing the effect of solvency, company size, company age, and audit opinions on audit delays is a research objective. The approach applied is the quantitative research method. The data processed comes from the website of the Indonesia Stock Exchange. The population in this study was 119 and a sample of 72 companies that are listed on the Indonesia Stock Exchange trade, service, and investment sector where the selection of samples using purposive sampling. The method used for statistical testing is the Logistic Regression and obtained solvency results, company size, and audit opinion do not affect audit delay, while the age of the company affects audit delay. The limitation of the research is to only process data based on data from the official website of the indonesia stock exchange trade, service, and investment sector for the period 2017-2019 and focus on research variables. This research is expected to be input and consideration for companies to report their report on time and for investors to be considered to decide their investment decisions and can contribute to filling the literature gap related to audit delay with the latest data 2017-2019.
\end{abstract}

Keywords: Audit delay; audit opinion; company age; company size; solvency

\section{PENDAHULUAN}

Terdaftarnya perusahaan di pasar modal memberikan manfaat bagi perusahaan karena dapat memperoleh dana yang besar dalam menunjang ekspansi usaha. Perusahaan yang terdaftar di pasar modal terdiri dari beberapa sektor, salah satu diantaranya adalah sektor trade, service, and investment yang bergerak di bidang jasa, perdagangan, dan investasi. Sebagai perusahaan terbuka, perusahaan memiliki kewajiban menyampaikan laporan keuangan tahunan dan laporan auditor independen perusahaan paling lambat sembilan puluh hari sesudah tanggal penutupan laporan keuangan dimana hal ini telah ditetapkan sesuai dengan Keputusan Ketua Badan Pengawa Modal No.36/PM/2003 (Rubianto, 2017). Jangka waktu antara tanggal penutupan tahun buku hingga tanggal diterbitnya laporan auditor independen disebut dengan audit delay (Ginanjar et al., 2019).

Dikeluarkannya peraturan terkait masa penyampaian laporan tahunan tidak berarti bahwa semua perusahaan mempublikasikan laporan keuangan perusahaan tepat waktu. Hal tersebut terbukti dari pengumuman yang dikeluarkan oleh Bursa Efek Indonesia tanggal 2 April 2018 yang menyatakan untuk periode 31 Desember 2017 masih terdapat 70 perusahaan yang belum melakukan kewajibannya, 6 diantaranya merupakan perusahan tercatat sektor trade, service, and investment. Pengumuman bulan Mei 2019 diungkapkan bahwa terdapat 24 perusahaan yang belum menyampaikan laporan tahunannya periode 31 Desember 2018, dimana satu diantaranya merupakan perusahaan sektor trade, service and investment. Sedangkan pengumuman pada tanggal 2 Juni 2020 diberitakan bahwa pada periode 31 Desember 2019 terdapat 64 perusahaan yang belum menyampaikan laporan tahunanya dan satu diantaranya merupakan perusahaan yang tercatat ke 
dalam sektor trade, service and investment.

Perusahaan dapat dipandang buruk oleh publik apabila mengalami audit delay yang lama karena umumnya masyarakat akan berpikir bahwa perusahaan tersebut memiliki kondisi keuangan yang tidak baik. Selain itu, penilaian terhadap perusahaan juga dinilai dari tata kelola perusahaan dimana hal ini dapat tercermin dari kemampuan perusahaan melaksanakan segala kewajibannya, salah satunya adalah melaporkan laporan tahunannya tepat waktu. Hal tersebut menerangkan bahwa audit delay penting bagi perusahaan.

Fakta terkait maraknya perusahaan mengalami audit delay diduga dikarenakan adanya pengaruh dari kepemilikan hutang yang tinggi di perusahaan (Effendi, 2018) dan nyatanya tidak selalu perusahaan yang memiliki aset sedang yang mengalami audit delay, nyatanya perusahaan yang memiliki aset yang besar juga mengalaminya (Diana, 2017). Tetapi masih terdapat banyak faktor yang dapat dijadikan penyebab perusahaan mengalami audit delay, tidak hanya selalu kepemilikan hutang dan kepemilikan aset saja (Lestari \& Putu, 2017).

Aspek lain penyebab lamanya audit delay juga disebabkan oleh seberapa lama perusahaan tersebut berdiri (Saputra et al., 2020) dan perusahaan yang memperoleh opini audit berupa wajar tanpa pengecualian mengalami audit delay yang singkat daripada perusahaan yang mendapatkan opini audit berupa tidak memberikan pendapat (Marni et al., 2019). Namun nyatanya masih terdapat aspek lain yang mempengaruhi audit delay, tidak hanya disebabkan oleh lama atau tidaknya perusahaan tersebut berdiri (Diana, 2017) dan bentuk dari opini audit saja (Saputra et al., 2020).

Mengacu kepada penelitian sebelumnya yang telah dilakukan oleh Diana (2017) yang meneliti pengaruh ukuran perusahaan, umur perusahaan dan opini audit, peneliti mengembangkan penelitian tersebut dengan menambahkan variabel bebas solvabilitas serta periode penelitian terbaru yakni 2017-2019 dan fokus penelitian pada sektor trade, service, and investment dengan harapan bahwa penelitian ini menjadi masukan dan pertimbangan bagi perusahaan sehingga dapat melaporkan laporan tahunannya tepat waktu dan sebagai bahan pertimbangan investor dalam memutuskan keputusan investasinya serta dapat berkontribusi untuk mengisi kesenjangan literatur terkait audit delay dengan data terbaru 2017-2019.

\section{Teori Signaling}

\section{STUDI LITERATUR}

Teori signaling merupakan suatu sinyal yang diterima investor atau pihak eksternal perusahaan yang diperoleh dari tindakan pihak manajemen perusahaan terkait prospek perusahaan ( $\underline{\text { Sari \& }}$ Mulyani, 2019). Sinyal yang diperoleh investor atau pihak eksternal perusahaan merupakan suatu informasi yang dapat menjadi pertimbangan dalam melakukan keputusan investasi. Entitas yang menyampaikan laporan tahunannya tepat waktu merupakan entitas dengan prospek yang dipandang baik, sebaliknya entitas yang menyampaikan laporan tahunannya tidak tepat waktu dinilai memiliki prospek yang buruk (Sari \& Mulyani, 2019). Rendahnya hutang perusahaan, perusahaan besar, perusahaan yang berdiri lama, perusahaan yang mendapatkan opini audit berupa wajar tanpa pengecualian diduga memberikan sinyal bagi investor bahwa perusahaan mengalami audit delay yang singkat karena memiliki prospek yang baik daripada perusahaan dengan hutang yang tinggi, perusahaan kecil, perusahaan yang belum lama berdiri serta perusahaan yang mendapatkan opini audit berupa tidak memberikan pendapat.

\section{Laporan Keuangan}

Laporan keuangan merupakan alat komunikasi perusahaan terkait kondisi keuangan perusahaan yang disampaikan kepada pihak eksternal perusahaan (Hakim \& Sagiyanti, 2018). Standar kualitas laporan keuangan yaitu: mudah dimengerti, memberikan informasi yang sejalan dengan kebutuhan pengguna (relevan), materialistis, memiliki kualitas yang andal bebas dari kesalahan material dan serta menyajikan secara jujur (andal/reliabilitas), disajikan dengan substansi dan realitas ekonomi bukan hanya bentuk hukumnya (substansi mengungguli bentuk), tidak mengabaikan ketidakpastian yang meliputi berbagai peristiwa dan keadaaan yang dipahami berdasarkan pengungkapan sifat serta penjelasan atas peristiwa dan keadaan tersebut (pertimbangan yang sehat), informasi harus lengkap menurut batasan materialitas dan biaya (kelengkapan), pengguna dapat membandingkan laporan keuangan entitas antarperiode ataupun 
antarentitas (dapat dibandingkan/komparabilitas), penyediaan informasi laporan keuangan dalam jangka waktu pengambilan keputusan (tepat waktu), serta keseimbangan antara biaya dan manfaat (Hery, 2017).

\section{Auditing}

Auditing merupakan proses sistematis untuk memperoleh dan mengevaluasi (secara obyektif) bukti yang berhubungan dengan asersi tentang tindakan-tindakan dan kejadian ekonomi, dalam rangka menentukan tingkat kepatuhan antara asersi dengan kriteria yang ditetapkan, serta mengkomunikasikan hasilnya kepada pihak-pihak yang berkepentingan (Hery, 2017). Tujuan audit adalah untuk menyampaikan opini atas laporan keuangan perusahaan sesuai dengan prinsip akuntansi yang berlaku (Sari \& Mulyani, 2019). Standar umum auditing terdiri dari standar umum, standar pekerjaan lapangan, dan standar pelaporan (Hery, 2017). Salah satu langkah penting dalam proses audit adalah membuat laporan auditor independen. Laporan auditor independen adalah laporan yang mengkomunikasikan temuan-temuan auditor pada saat proses audit (Julia, 2020).

\section{Hubungan Solvabilitas dan Audit Delay}

Baik tidaknya rasio kemampuan perusahaan membayar segala hutangnya adalah dengan membandingkan nilai rasionya dengan rata-rata rasio yang dimiliki perusahaan dibidang yang sama. Namun, secara umum rasio yang dimiliki perusahaan harus di bawah 0,5 (Hery, 2020). Tingginya solvabilitas mengindikasikan hutang yang banyak daripada aset, dimana hal ini berarti kemampuan perusahaan dalam menyelesaikan kewajibannya adalah lemah, sehingga auditor lebih teliti dalam menjalankan auditing yang berdampak pada lamanya audit delay (Effendi, 2018). Hal ini juga dibuktikan dengan hasil penelitian Diana (Diana, 2017).

$\mathrm{H} 1$ : Solvabilitas berpengaruh terhadap audit delay

\section{Hubungan Ukuran Perusahaan dan Audit Delay}

Perusahaan besar cenderung dimonitor secara ketat pihak eksternal, seperti investor dan pihak pemerintah sehingga mendapatkan tekanan yang membuat perusahaan melakukan publikasi laporan tahunan lebih cepat (Lestari \& Putu, 2017).Penelitian dari Saputra,Irawan, dan Ginting mengungkapkan bahwa besar kecilnya perusahaan dapat mempengaruhi lamanya audit delay (Saputra et al., 2020).

$\mathrm{H} 2$ : Ukuran perusahaan berpengaruh terhadap audit delay

\section{Hubungan Umur Perusahaan dan Audit Delay}

Perusahaan yang berdiri lama dinilai lebih cakap dalam menyiapkan keperluan yang dibutuhkan untuk proses audit karena memiliki pengalaman terkait hal tersebut sehingga dapat mempersingkat audit delay (Diana, 2017). Hasil dari penelitian Saputra, Irawan, dan Ginting mengungkapkan bahwa terdapat pengaruh variabel umur perusahaan terhadap audit delay (Saputra et al., 2020)

H3 : Umur perusahaan berpengaruh terhadap audit delay

\section{Hubungan Opini Audit dan Audit Delay}

Lamanya publikasi laporan keuangan auditan juga dikarenakan jenis dari opini audit yang diperoleh perusahaan. Hal ini dikarenakan auditor akan lebih teliti ketika perusahaan memperoleh opini berupa tidak memberikan pendapat sehinga berdampak pada lamanya audit delay (Mahendra \& Widhiyani, 2017) yang sejalan dengan hasil penelitian Marni, Ali, dan Yeni (Marni et al., 2019). Lima jenis opini audit yaitu: pendapat wajar tanpa pengecualian, pendapat wajar tanpa pengecualian dengan bahasa yang ditambahkan dalam laporan audit bentuk baku, pendapat wajar dengan pengecualian, pendapat tidak wajar, dan pernyataan tidak memberikan pendapat (Siahaan et al., 2019).

$\mathrm{H} 4$ : Opini audit berpengaruh terhadap audit delay

\section{METODE}

Berikut ini merupakan tabel definisi operasional yang berisikan penjelasan masing-masing variabel penelitian : 
Tabel 1. Definisi Operasional

\begin{tabular}{|c|c|c|}
\hline Variabel & Definisi & Indikator \\
\hline Solvabilitas & $\begin{array}{l}\text { Kemampuan perusahaan } \\
\text { membayar seluruh hutang } \\
\text { yang dimiliki (Syachrudin \& } \\
\text { Nurlis, 2018) }\end{array}$ & $\begin{array}{l}\text { Debt to Asset Ratio }(D A R)=\frac{\text { Total liabiltas }}{\text { Total aset }} \\
\text { Sumber: (Sukamulja, 2019) }\end{array}$ \\
\hline $\begin{array}{l}\text { Ukuran } \\
\text { Perusahaan }\end{array}$ & $\begin{array}{ll}\text { Besar kecilnya } & \text { perusahaan } \\
\text { (Wulandari \& } & \text { Wiratmaja, } \\
\text { 2017). } & \\
\end{array}$ & $\begin{array}{l}\text { Ukuran Perusahaan }=\log (\text { total aset }) \\
\text { Sumber: (Lestari \& Putu, 2017) }\end{array}$ \\
\hline $\begin{array}{l}\text { Umur } \\
\text { Perusahaan }\end{array}$ & $\begin{array}{l}\text { Lamanya perusahaan berdiri } \\
\text { (Diana, 2017). }\end{array}$ & $\begin{array}{l}\text { Umur perusahaan dihitung dari tanggal pendirian } \\
\text { perusahaan sampai tangal penutupan laporan } \\
\text { keuangan perusahaan (Julia, 2020). }\end{array}$ \\
\hline $\begin{array}{l}\text { Opini } \\
\text { Audit }\end{array}$ & $\begin{array}{l}\text { Pernyataan auditor } \\
\text { berdasarkan kesimpulan yang } \\
\text { diperoleh pada saat proses } \\
\text { audit yang sesuai dengan } \\
\text { standar yang berlaku (Tullah } \\
\text { et al., 2019). }\end{array}$ & $\begin{array}{l}\text { Kode dummy } 0 \text { untuk pendapat yang berupa : } \\
\text { pendapat wajar tanpa pengecualian, pendapat } \\
\text { wajar tanpa pengecualian dengan bahasa yang } \\
\text { ditambahkan dalam laporan audit bentuk baku, } \\
\text { pendapat wajar dengan pengecualian, kode } \\
\text { dummy } 1 \text { untuk pendapat tidak wajar dan } \\
\text { pernyataan tidak memberikan pendapat. }\end{array}$ \\
\hline $\begin{array}{l}\text { Audit } \\
\text { Delay }\end{array}$ & $\begin{array}{l}\text { Lamanya waktu penyelesaian } \\
\text { audit dihitung dari tanggal } \\
\text { penutupan tahun buku hingga } \\
\text { tanggal diterbitkannya } \\
\text { laporan audit (Wulandari \& } \\
\text { Wiratmaja, 2017). }\end{array}$ & 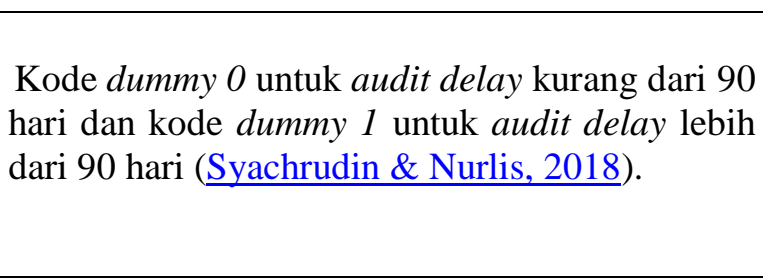 \\
\hline
\end{tabular}

Sumber tabel : data diolah dari beberapa jurnal

Perusahaan terbuka sektor trade, service, and investment sesuai dengan data perusahaan tercatat Bursa Efek Indonesia periode 2017-2019 merupakan tempat penelitian dimana data diperoleh dari laporan keuangan yang dipublikasikan pada website Bursa Efek Indonesia https://www.idx.co.id sehingga menunjukkan bahwa jenis data penelitian yaitu data sekunder.

Hipotesis dianalisis dengan menggunakan data bersifat statistik sehingga penelitian ini menggunakan bentuk penelitian kuantitatif. Metode penelitian kuantitatif merupakan pengujian hipotesis dengan analisis data berupa kuantitatif atau statistik (Sugiyono, 2018).

Perusahaan terbuka tercatat di Bursa Efek Indonesia tepatnya sektor trade, service, and investment periode 2017-2019 sebesar 119 perusahaan merupakan populasi dari penelitian ini. Pengambilan populasi tersebut didasarkan pada pengertian populasi yakni wilayah generalisasi dengan kualitas dan karakteristik peneliti (Sugiyono, 2018).

Bagian dari populasi yang memiliki karakteristik disebut dengan sampel. Peneliti menentukan sampel dengan menggunakan sampling purposive yakni memiliki kriteria tertentu yang sesuai dengan karakteristik dari peneliti (Sugiyono, 2018). Peneliti memutuskan untuk membuat kriteria sampel yaitu: entitas yang tercatat di sektor trade, service, and investment di Bursa Efek Indonesia periode 2017-2019, mempublikasikan laporan tahunan (terdiri dari laporan keuangan dan laporan auditor independen) setiap periode 2017-2019, dan laporan auditor independen yang jelas (dapat dibaca). Sehingga diperoleh 72 perusahaan yang dijadikan sebagai sampel penelitian. Peneliti melakukan penelitian dengan periode 2017-2019 atau selama 3 tahun sehingga data yang dikelola sebanyak 216 data. Persamaan regresi logistik yaitu:

$$
\ln \left[\frac{p}{1-p}\right]=\alpha+\beta_{1} \operatorname{Solv}+\beta_{2} U K P+\beta_{3} U M P+\beta_{4} O A+\varepsilon
$$


keterangan :

$$
\begin{array}{ll}
\ln \left[\frac{p}{1-p}\right] & =\text { Audit Delay } \\
\alpha & =\text { Konstanta } \\
\beta_{1}-\beta_{1} & =\text { Koefisien Paramete Struktur } \\
\text { Solv } & =\text { Solvabilitas } \\
\text { UKP } & =\text { Ukuran Perusahaan } \\
\text { UMP } & =\text { Umur Perusahaan } \\
\text { OA } & =\text { Opini Audit } \\
\varepsilon & =\text { Kesalahan Residual }
\end{array}
$$

Variabel bebas solvabilitas, ukuran perusahaan, dan umur perusahaan adalah variabel metrik, sedangkan variabel bebas opini audit termasuk variabel non-metrik. Variabel dependen audit delay merupakan variabel non-metrik.

Menurut Imam Ghozali (Ghozali, 2018) apabila variabel independen adalah kombinasi dari metrik dan non-metrik, serta jika terjadi penyimpangan asumsi normalitas multivariate maka sebaiknya menggunakan uji statistik logistic regression. Berdasarkan hal tersebut maka peneliti menggunakan regresi logistik untuk menguji hipotesis yang sebelumnya telah dinyatakan oleh peneliti. Berikut adalah persamaan regresi logistik diperoleh dari uji statistik :

$$
\ln \left[\frac{A D}{1-A D}\right]=22,742+0,093 \text { SOLV }-0,058 \text { UKP }-0,031 \text { UMP }-22,555 \text { OA }
$$

Dalam Regresi logistik, untuk menguji kualitas data dapat dilakukan dengan menilai Overall Fit Model (model fit data) diantaranya adalah membandingkan nilai -2LogL, uji Hosmer and Lemeshow's Test serta uji Nagelkerke R Square (Ghozali, 2018). Uji hipotesis dalam penelitian ini adalah dengan menilai wald signifikannya dan membandingkan dengan 0,05. Untuk mendeskripsikan seluruh variabel, peneliti akan memberikan hasil dari pengujian statistik deskriptif.

\section{HASIL}

Berikut ini adalah gambaran seluruh variabel berdasarkan pada hasil pengujian yang telah dilakukan:

Tabel 2. Descriptive Statistics

\begin{tabular}{|l|c|r|r|r|r|}
\hline \multirow{2}{*}{ SOLV } & $\mathbf{N}$ & Minimum & Maximum & Mean & Std. Deviation \\
\cline { 2 - 6 } & 216 & .01 & 4.37 & .5215 & .45374 \\
\hline UKP & 216 & 8.97 & 14.07 & 12.2499 & .84652 \\
\hline UMP & 216 & 3 & 115 & 30.26 & 17.169 \\
\hline OA & 216 & 0 & 1 & .00 & .068 \\
\hline AD & 216 & 0 & 1 & .21 & .410 \\
\hline Valid N(listwise) & 216 & & & & \\
\hline
\end{tabular}

Sumber tabel : hasil uji statistik (SPSS)

Hasil dari uji statistik yang telah dilakukan mengungkapkan bahwa nilai minimum dari variabel solvabilitas adalah 0,01 , ukuran perusahaan sebesar 8,97 , umur perusahaan adalah 3 , serta opini audit dan audit delay adalah 0 . Sedangkan nilai maksimum variabel solvabilitas sebesar 4,37, ukuran perusahaan 14,07, umur perusahaan 115 , dan opini audit serta audit delay adalah 1. Ratarata dari setiap variabel independen yaitu solvabilitas sebesar 0,5215, ukuran perusahaan 12,2499, umur perusahaan 30,26, opini audit sebesar 0, dan audit delay adalah 0,21. Dari tabel di atas, juga menunjukkan nilai dari standar deviasi solvabilitas sebesar 0,45374, ukuran perusahaan 0,84652, umur perusahaan 17,169, opini audit 0,068, dan audit delay 0,410 . 
Untuk menentukan apakah model regresi logistic sesuai dengan data, maka langkah awal yang dapat dilakukan yakni menilai overall fit model terhadap data yang dinilai dari 2LogLikelihood, Uji Hosmer and Lemeshow's Test, dan Naglekerke R Square (Ghozali, 2018).

Dalam penelitian ini, perbandingan nilai $-2 \log L$ digunakan untuk menguji fit atatu tidaknya model yang dihipotesakan. Berikut adalah hasil uji statistik yang menunjukkan nilai dari 2LogLikelihood awal :

Tabel 3. -2LogL (Awal)

\begin{tabular}{|c|c|c|c|}
\hline \multirow{2}{*}{\multicolumn{2}{|c|}{ Iteration }} & \multirow{2}{*}{-2 Log likelihood } & Coefficients \\
\hline & & & Constant \\
\hline \multirow[t]{4}{*}{ Step 0} & 1 & 224.657 & -1.148 \\
\hline & 2 & 223.715 & -1.301 \\
\hline & 3 & 223.714 & -1.307 \\
\hline & 4 & 223.714 & -1.307 \\
\hline
\end{tabular}

Sumber tabel : hasil uji statistik (SPSS)

Hasil uji statistik pada tabel 3 mengungkapkan bahwa nilai -2LogL awal adalah 223,714 . Nilai -2LogL awal merupakan hasil model yang hanya memasukkan konstanta saja tanpa memasukkan variabel bebas penelitian. Berikut merupakan hasil uji statistik yang menunjukkan nilai dari -2LogLikelihood akhir :

Tabel 4. -2LogL (Akhir)

\begin{tabular}{|c|c|c|c|c|c|c|c|}
\hline \multirow{2}{*}{\multicolumn{2}{|c|}{ Iteration }} & \multirow{2}{*}{$\begin{array}{l}-2 \text { Log } \\
\text { likelihood }\end{array}$} & \multicolumn{5}{|c|}{ Coefficients } \\
\hline & & & Constant & SOLV & UKP & UMP & OA(1) \\
\hline \multirow{20}{*}{$\begin{array}{l}\text { Step } \\
1\end{array}$} & 1 & 216.810 & 2.889 & .050 & -.042 & -.015 & -3.110 \\
\hline & 2 & 213.872 & 4.545 & .085 & -.057 & -.027 & -4.443 \\
\hline & 3 & 213.718 & 5.713 & .093 & -.058 & -.031 & -5.529 \\
\hline & 4 & 213.698 & 6.734 & .093 & -.058 & -.031 & -6.546 \\
\hline & 5 & 213.691 & 7.739 & .093 & -.058 & -.031 & -7.552 \\
\hline & 6 & 213.689 & 8.741 & .093 & -.058 & -.031 & -8.554 \\
\hline & 7 & 213.688 & 9.742 & .093 & -.058 & -.031 & -9.555 \\
\hline & 8 & 213.688 & 10.742 & .093 & -.058 & -.031 & -10.555 \\
\hline & 9 & 213.687 & 11.742 & .093 & -.058 & -.031 & -11.555 \\
\hline & 10 & 213.687 & 12.742 & .093 & -.058 & -.031 & -12.555 \\
\hline & 11 & 213.687 & 13.742 & .093 & -.058 & -.031 & -13.555 \\
\hline & 12 & 213.687 & 14.742 & .093 & -.058 & -.031 & -14.555 \\
\hline & 13 & 213.687 & 15.742 & .093 & -.058 & -.031 & -15.555 \\
\hline & 14 & 213.687 & 16.742 & .093 & -.058 & -.031 & -16.555 \\
\hline & 15 & 213.687 & 17.742 & .093 & -.058 & -.031 & -17.555 \\
\hline & 16 & 213.687 & 18.742 & .093 & -.058 & -.031 & -18.555 \\
\hline & 17 & 213.687 & 19.742 & .093 & -.058 & -.031 & -19.555 \\
\hline & 18 & 213.687 & 20.742 & .093 & -.058 & -.031 & -20.555 \\
\hline & 19 & 213.687 & 21.742 & .093 & -.058 & -.031 & -21.555 \\
\hline & 20 & 213.687 & 22.742 & .093 & -.058 & -.031 & -22.555 \\
\hline
\end{tabular}

Sumber tabel : hasil uji statistik (SPSS)

Hasil uji statistik -2LogL akhir menghasilkan model yang memasukkan konstanta dan semua variabel bebas sebesar 213,687.Selisih dari kedua -2LogL sebesar 10,027 $(223,714-213,687)$ yang mengindikasikan terjadi penurunan nilai. Terjadinya penurunan nilai ini mengungkapkan penambahan variabel bebas solvabilitas, ukuran perusahaan, umur perusahaan dan opini audit ke dalam model pengujian fit dengan data.

Dalam menilai tepat atau tidaknya model yang dibentuk dengan data penelitian digunakan uji Hosmer and Lemeshow's Test. Diindikasikan tepat apabila nilai signifikannya melebihi 0,05. 
Besarnya pengaruh variabel independen terhadap variabel dependen dapat diketahui dengan menggunakan uji Nagelkerke R Square. Berikut hasil pengujian statistik :

Tabel 5. Hosmer and Lemeshow's Test \& Nagelkerke R Square

\begin{tabular}{|c|c|c|c|}
\hline Step & Chi-square & Df & Sig. \\
\hline 1 & 8.513 & 8 & .385 \\
\hline Step & $\mathbf{- 2 ~ L o g ~ l i k e l i h o o d ~}^{\text {Cox \& Snell R }}$ & $\begin{array}{c}\text { Nagelkerke R } \\
\text { Square }\end{array}$ \\
\hline 1 & $213.687^{\text {a }}$ & .045 & .070 \\
\hline
\end{tabular}

Sumber tabel : hasil uji statistik (SPSS)

Uji statistik Hosmer and Lemeshow's Test yang dilakukan mengungkapkan model yang dibentuk sudah tepat dikarenakan nilai signifikannya adalah 0,385 dimana angka tersebut melebihi 0,05 . Nilai signifikan Nagelkerke $R$ Square dari tabel 5 yakni 0,070 menunjukkan besarnya pengaruh solvabilitas, ukuran perusahaan, umur perusahaan dan opini audit terhadap audit delay adalah $7 \%(0,070 \times 100 \%)$.

Berpengaruh atau tidak berpengaruhnya independent variable secara parsial terhadap dependent variable dapat dinilai dari wald sig. yang dimiliki masing-masing variabel. Dikatakan berpengaruh apabila nilai tersebut kurang dari 0,05 dan sebaliknya dikatakan tidak berpengaruh apabila nilai wald sig. melebihi 0,05 . Berikut merupakan data yang diperoleh dari hasil uji statistik

Tabel 6. Hasil Uji Hipotesis

\begin{tabular}{|l|l|l|l|}
\hline No. & Hipotesis & Sig. & Status \\
\hline 1. & $\begin{array}{l}\text { H1 : solvabilitas berpengaruh } \\
\text { terhadap audit delay }\end{array}$ & 0,801 & Ditolak \\
\hline 2 & $\begin{array}{l}\text { H2 : ukuran perusahaan } \\
\text { berpengaruh terhadap audit delay }\end{array}$ & 0,775 & Ditolak \\
\hline 3 & $\begin{array}{l}\text { H3: umur perusahaan berpengaruh } \\
\text { terhadap audit delay }\end{array}$ & 0,021 & Diterima \\
\hline 4 & $\begin{array}{l}\text { H4: opini audit berpengaruh } \\
\text { terhadap audit delay }\end{array}$ & 1,000 & Ditolak \\
\hline
\end{tabular}

Sumber tabel : data diolah dari hasil uji statistik

\section{PEMBAHASAN}

Rendah atau tidaknya kemampuan perusahaan dalam membayar segala kewajibannya tidak mempengaruhi audit delay perusahaan sebab dalam proses audit, auditor telah memberikan informasi kepada klien terkait hal-hal yang dibutuhkan baik dalam bentuk dokumen ataupun yang lainnya sehingga tidak menghabiskan waktu yang lama ketika proses audit dilaksanakan. Hasil ini tidak sejalan dengan teori signaling dimana rendahnya utang perusahaan memberikan sinyal bagi investor bahwa perusahaan mengalami audit delay yang singkat. Nyatanya, perusahaan yang memiliki solvabilitas tinggi juga mendapati audit delay yang singkat. Penelitian Lestari dan Putu juga mengungkapkan hal yang sama bahwa tinggi rendahnya solvabilitas tidak memiliki pengaruh terhadap audit delay (Lestari \& Putu, 2017).

Ukuran Perusahaan tidak mempengaruhi audit delay dibuktikan juga dengan penelitian Rubianto (Rubianto, 2017). Hasil ini tidak sejalan dengan teori signaling dimana perusahaan yang berukuran besar mengalami audit delay yang singkat daripada perusahaan kecil. Nyatanya, perusahaan kecil pun dapat mengalami audit delay yang singkat.Hal ini dapat terjadi karena auditor dalam melaksanakan proses audit adalah secara profesional sehingga dalam melakukan tugas dan kewajibannya adalah sesuai dengan prosedur audit tanpa melihat ukuran dari perusahaan tersebut.

Hasil penelitian yang menyatakan umur perusahaan memiliki pengaruh terhadap audit delay dinyatakan juga oleh Saputra,Irawan, dan Ginting (Saputra et al., 2020). Hal ini sejalan dengan teori signaling perusahaan dimana audti delay yang singkat dialami oleh perusahaan yang telah berdiri lama dibandingkan dengan perusahaan yang baru berdiri. Perusahaan yang telah melakukan 
kegiatan operasional yang cukup lama dinilai dapat lebih cakap dalam melakukan segala kewajibannya dibandingkan dengan perusahaan yang belum lama beroperasi. Kecakapan perusahaan dalam menyiapkan segala hal yang diperlukan dalam proses audit dapat mengakibatkan waktu yang diperlukan saat auditing akan lebih sedikit dikarenakan perusahaan telah berpengalaman terkait hal tersebut.

Berdasarkan pengujian yang dilakukan, diperoleh hasil bahwa Opini audit tidak memiliki pengaruh terhadap audit delay yang relevan dengan penelitian Saputra, Irawan, dan Ginting (Saputra et al., 2020), sehingga diperoleh hasil bahwa ini tidak sejalan dengan teori signaling yakni audit delay yang singkat diduga didapati oleh perusahaan yang mendapatkan opini audit berupa wajar tanpa pengecualian daripada perusahaan yang mendapatkan opini berupa tidak memberikan pendapat karena auditior akan lebih teliti dalam menjalankan proses audit ketika perusahaan mendapatkan opini berupa pernyataan tidak memberikan pendapat. Pada nyatanya, perusahaan yang mendapati opini audit berupa wajar tanpa pengecualian juga mengalami audit delay yang panjang. Auditor dalam melakukan tugasnya adalah dengan profesional, secara teliti baik saat mengeluarkan opini audit tidak memberikan pendapat maupun disaat mengeluarkan opini audit berupa wajar tanpa pengecualian.

\section{KESIMPULAN}

Peneliti menarik kesimpulan berdasarkan pembahasan sebelumnya, yaitu: solvabilitas, ukuran perusahaan, dan opini audit tidak berpengaruh terhadap audit delay atau dengan kata lain $\mathrm{H} 1, \mathrm{H} 2$, dan H4 ditolak, sedangkan umur perusahaan mempengaruhi audit delay atau H3 diterima. Keterbatasan dari penelitian ini adalah penelitian hanya mengolah data berdasarkan data yang terdapat di website resmi Bursa Efek Indonesia periode 2017-2019 yang berfokus pada sektor trade, service, and investment, serta hanya melakukan penelitian berdasarkan variabel bebas dari penelitian ini yakni solvabilitas, ukuran perusahaan, umur perusahaan, dan opini audit, dan variabel terikat penelitian yaitu audit delay.

\section{REFERENSI}

Diana, A. L. (2017). Perusahaan dan Opini Auditor terhadap Audit Delay. Jurnal AKuntansi dan Manajemen, 13(01), 21-41.

Effendi, B. (2018). Profitabilitas, Solvabilitas dan Audit Delay pada Perusahaan Consumer Goods yang terdaftar di BEI. OWNER: Riset \& Jurnal Akuntansi, 2(2), 1-9.

Ghozali, I. (2018). Aplikasi Analisis Multivariat dengan Program IBM SPSS 25 (9th ed.). Badan Penerbit Universitas Diponegoro.

Ginanjar, Y., Rahmayani, M. W., \& Riyadi, W. (2019). Identifikasi Faktor Penyebab Tingkat Audit Delay di Bursa Efek Indonesia. Jurnal Kajian Akuntansi, 3(2), 210. https://doi.org/10.33603/jka.v3i2.2628

Hakim, L., \& Sagiyanti, P. (2018). Pengaruh Ukuran Perusahaan, Jenis Industri, Komite Audit, dan Ukuran KAP terhadap Audit Delay. Jurnal Dinamika Manajemen, 1(2), 58-73. https://publikasi.mercubuana.ac.id/index.php/jdm/article/view/4125

Hery. (2017). Auditing and Asurans (Adipramono (ed.)). PT Grasindo.

Hery. (2020). Analisis Laporan Keuangan (Adipramono (ed.); 6th ed.). PT Grasindo.

Julia. (2020). Effect Financial Ratio, Company Age, Size Public Accountant Firm in Audit Delay. Jurnal Akuntansi, 24(1), 51. https://doi.org/10.24912/ja.v24i1.641

Lestari, K. A. N. M., \& Putu, W. S. (2017). Analisis Pengaruh Ukuran Perusahaan, Profitabilitas, Solvabilitas, Kualitas Auditor dan Audit Tenure Terhadap Audit Delay pada Perusahaan Manufaktur di Bursa Efek Indonesia Periode 2012-2015. Jurnal Ilmiah Manajemen \& Bisnis, 23(1), 1-11.

Mahendra, A. A. N. P., \& Widhiyani, N. L. S. (2017). Pengaruh GCG, Opini Auditor, dan Internal Auditor terhadap Audit Delay pada Perusahaan TELEKOMUNIKASI di BEI. E-Jurnal Akuntansi Universitas Udayana, 21, 1601-1629.

Marni, Ali, S., \& Yeni, N. S. (2019). The Influence of Government Size, Audit Opinion and Incumbent on Audit Delay in the Provincial Government in Indonesia. International Journal of Progressive Sciences and Technologies, 12(2), 118-126. http://ijpsat.ijsht- 
journals.org/index.php/ijpsat/article/view/674/376

Rubianto, A. V. (2017). The Analysis on Factors Affecting Audit Delay on Manufacturing Companies Listed in Indonesia Stock Exchange. Jurnal Riset Dan Aplikasi Akuntansi dan Manajemen, 2(3), 205. https://doi.org/10.18382/jraam.v2i3.207

Saputra, A. D., Irawan, C. R., \& Ginting, W. A. (2020). Pengaruh Ukuran Perusahaan, Opini Audit, Umur Perusahaan, Profitabilitas dan Solvabilitas terhadap Audit Delay. OWNER: Riset \& Jurnal Akuntansi, 4(2), 286. https://doi.org/10.33395/owner.v4i2.239

Sari, D. P., \& Mulyani, E. (2019). Faktor-Faktor yang mempengaruhi Audit Delay (Studi Empiris pada Perusahaan Pertambangan yang terdaftar di Bursa Efek Indonesia Tahun 2014-2017). Jurnal Eksplorasi Akuntansi, 1(2), 648. http://jea.ppj.unp.ac.id/index.php/jea/issue/view/6

Siahaan, I., Surya, R. A. S., \& Zarefar, A. (2019). Pengaruh Opini Audit, Pergantian Auditor, Kesulitan Keuangan, dan Efektivitas Komite Audit terhadap Audit Delay (Studi Empiris pada Seluruh Perusahaan yang Terdaftar di Bursa Efek Indonesia Tahun 2014- 2017). Jurnal Akuntansi Keuangan dan Bisnis, 12(2), 135-144. https://jurnal.pcr.ac.id/index.php/jakb/

Sugiyono. (2018). Metode Penelitian Kuantitatif, Kualitatif, dan R\&D. Alfabeta.

Sukamulja, S. (2019). Analisa Laporan Keuangan sebagai Dasar Pengambilan Keputusan Investasi. ANDI.

Syachrudin, D., \& Nurlis. (2018). Influence of Company Size, Audit Opinion, Profitability, Solvency, and Size of Public Accountant Offices to Delay Audit on Property Sector Manufacturing Companies listed in Indonesia stock Exchange. International Journal of Scientific and Technology Research, 7(10), 106-111.

Tullah, D. S., Apriyanti, E., \& Rianti, F. (2019). Pengaruh Ukuran Daerah, Opini Audit dan Tingkat Ketergantungan Keuangan Daerah terhadap Audit Delay. ATESTASI: Jurnal Ilmiah Akuntansi, 2(2), 87-97. https://doi.org/10.33096/atestasi.v2i2.271

Wulandari, N. P. I., \& Wiratmaja, I. dewa N. (2017). Pengaruh Audit Tenure dan Ukuran Perusahaan Klien terhadap Audit Delay dengan Financial Distress sebagai Pemoderasi. EJurnal Akuntansi Universitas Udayana, 21(1), 701-729.

$\underline{\text { www.idx.co.id }}$ 